\title{
Factors influencing profitability of conventional banks as measured by Tobin's q: evidence from banking sector of Pakistan
}

\author{
Jo-Ann Rolle \\ Dean, School of Business \\ Medgar Evers College, The City University, New York, USA \\ Gobind M. Herani \\ Dean, Dadabhoy Institute of Higher Education, Paqkistan \\ Bushra Javed \\ Institute of Business Management, Karachi, Pakistan
}

\begin{abstract}
Keywords
Bank specific factors, macro-economic determinants, banking sector, Tobin's $Q$ ratio, Profitability.
\end{abstract}

\begin{abstract}
Financial sector is the key player to enhance sustainable economic growth. Commercial banks play an important role to improve the performance of the financial sector of the economy and their profitability is intricately connected to the soundness of the entire economy. The purpose of this study is to determine the internal determinants (bank specific) and external determinants (macro-economic) of profitability. In this regard, the study adopted quantitative research design by using the panel data of 17 commercial banks of Pakistan over the period of 2014-2018. Internal factors analyzed in this study were Liquidity, Size and Capital Adequacy. While external factors were Gross Domestic Product $(G D P)$ and Inflation. The data was analyzed by using simple OLS regression and Tobin's $Q$ ratio. The analysis showed that GDP has significant impact on profitability. However, inflation has no impact on the profitability. Tobin's $Q$ ratio of most of the banks are increasing which depicted their equilibrium position. Based on the findings, the study recommended some policies that will encourage banks to reduce credit risk and minimize their liquidity holdings. Moreover, Government should take the proper initiatives to enhance the confidence of investors towards stock market.
\end{abstract}

\section{Introduction}

Banks contribute significantly to the growth and development of the economy. Banks provide assistance in the financial development of the country as well as provide various opportunities to people to make investment and saving plans through verified and guaranteed methods of investments (Sufian \& Habibullah, 2009). Profitability of banking sector contribute not only in economic growth, but also helps to bear the external and negative financial shocks (Athanasoglou, Brissimis, \& Delis, 2008). Rose (1999) described Profitability as the after-tax net income usually measured by return on assets and return on equity. Profitability is the capability of the company to produce earnings. There are many macroeconomic factors that affect profitability including real interest rate, inflation rate, real gross domestic product, and imports and exports of a country. Therefore, it seems very crucial to investigate the determinants of the profitability. The major concern is profitability and there are numerous external and internal factors that have some effects on the profitability of the banks. Internal factors they mostly consist of liquidity, capitalization, bank size, and operating efficiency. Conversely, external factors include Inflation and GDP.

Banks perform the duties of intermediary between the investors and end users and facilitate them in different business activities. Banking sector represented as the hub of financial sector with $88 \%$ share in last 10 years in Pakistan. Currently, there are 24 scheduled and cooperative banks (commercial banks) in Pakistan. Out of which, 17 conventional banks are listed in Pakistan Stock Exchange. Banking sector of Pakistan remained under the implementation of constant reforms and structural changes. Since 1947, several commercial banks have been merged to implement the structural reforms. Commercial banks showed remarkable growth in 1970. The maximum share of total assets around $90 \%$ of banks were hold 
by financially unproductive public banks in the period of 1980 to 1990. As a result, the profits decreased and ultimately, banking sector reforms were indulged in addressing these issues like lending rates and privatization etc. (Anwar, 2011). After the registration of banks in stock exchange and with the beginning of Islamic banking in 2002, the banks started to perform effectively and earned huge profits even in global financial crisis of 2008-2009. Commercial banks played very considerable role in the growth and development of economy. But, they are also badly affected due to the bad macroeconomic conditions in past decade (Ahmad, Nafees, \& Khan, 2012). Pakistani banks faced the challenges of financial instability due to the adjustments in the economic indicators.

Pakistan is dominated by commercial banks. Hence, it is necessary to analyze the association of their profitability with the development of Pakistan. Financial reports presented the financial results and related information to different stakeholders including investors, customers, and regulators. Financial reports also explain how company performed over a specific time and helpful to make investment decisions. The relevant information is provided by such financial reporting activity for making important business decisions (Dubelaar, Sohal, \& Savic, 2005). Therefore, this study is conducted to identify the most important external and internal factors on the profitability of conventional banks and also analyze the current market situation of banks for investors that would be able to add the strategies to enhance the development of the banks.

\subsection{Research Questions}

1.1.1 Does macroeconomic factor GDP affect the bank's performance significantly?

1.1.2 Does macroeconomic factor Inflation affect the bank's performance significantly?

1.1.3 Does macroeconomic factor Liquidity affect the bank's performance significantly?

1.1.4 Does macroeconomic factor Size affect the bank's performance significantly?

1.1.5 Does macroeconomic factor Capital Adequacy affect the bank's performance significantly?

Research Objectives

1.2.1 To determine the impact of GDP on Return on Assets.

1.2.2 To determine the impact of Inflation on Return on Assets

1.2.3 To determine the impact of Liquidity on Return on Assets.

1.2.4 To determine the impact of Size on Return on Assets.

1.2.5 To determine the impact of Capital Adequacy on Return on Assets.

1.3 Scope of the study

The banking sector is a speedily growing industry of Pakistan. Abidi and Lodhi (2015) stated that commercial banks play an important role in the economic development of Pakistan. There is much competition in occupying a superior position in financial system that every bank is trying to improve the overall performance along with profitability (Rashid \& Jabeen, 2016). There is a significant contribution of several industry-specific, bank-specific financial and macroeconomic factors in banking structure and performance. Therefore, this study aims to determine the impact of bank specific factors and macroeconomic factors on Return on Assets. 24 commercial banks are working in Pakistan. we have selected 17 listed conventional banks over the period of 2013-2017.

\section{Literature Review}

\subsection{Theoretical Background}

The profitability of a bank may be affected due to different variables. A portion of these variables can positively influence the profitability of banks, while others have negative affect. Some of these factors that influence the productivity of a bank may be under the control of the banks administration and the others may be out of control. Mostly internal factors are under the control of bank's administration. These are also called bank specific factors and they can be treated as positive or negative based on their specific effect on the profitability of the bank. These variables may identify as credit risk, capital structure, loan portfolio management, liquidity management, expense management and diversification of the products/ services of the bank. The external variables which are out of control by the management may incorporate components identified with the dimension of rivalry in the business to which the bank has a place (concentration), boundaries identified with passage to and exit from the business, the pace of economic 
development, the nature of the guidelines and supervision of the banks, inflation, money related extending, and fiscal policies and monetary policies (Rao \& Lakew, 2012).

\subsection{Variables}

This study designs the equation to measure the determinants of the profitability. To measure the influential determinants of conventional banks, the hypothesis of the research is as under:

\subsubsection{Relationship of GDP and bank's Performance}

GDP is one of the essential macroeconomic indicators which is used to measure the strength of the economy of a nation, and it is a proportion of the general financial yield inside a nation's fringes over a specific time, more often a year. Economic development and financial segment performance are significantly positively connected (Levine, Loayza, \& Beck, 2000). The real GDP development is relied upon to positively affect the bank's productivity. Fani, Khan, Kumar, and Kumar (2018) analyzed the effect of external and internal factors on the performance of banks and found that liquidity, capital adequacy, asset quality, and inflation have insignificant positive correlation with banks' performance. However, GDP, management efficiency, earning quality and stock market performance have significant positive correlation with bank's performance. Furthermore, Kamran, Johnson and Sammer (2016) have analysed the determinants of the bank's profitability in Pakistan and found that the GDP, Size and leverage ratio have significant effect on bank's profitability. Moreover, GDP was found to have significant positive affect on ROA and ROE (Bilal, Saeed, Gull, \& Akram, 2013). Another study conducted in Turkey by Anbar \& Alper (2011) by using the panel data analysis over the period 2002 to 2010, and found that Asset size, Non-interest income/assets and Real interest rate have Positive impact on ROA. However, Inflation, Capital ratio, Deposits/assets, Net interest margin and GDP have no significant effect on the profitability.

So, we propose that

H1= GDP has impact on ROA of Conventional Banks

\subsubsection{Relationship of Inflation and bank's performance}

Zopounidis and Kosmidou (2008) stated that there is a relationship between inflation and performance of the banks. To investigate the association between the macroeconomic factors, financial performance and firm characteristics of manufacturing companies in Nigeria, a study was conducted by Egbunike and Okerekeoti (2018) by using multiple linear regressions to validate the hypothesis and found no significant effect for exchange rate and interest rate, but found significant effect for inflation rate and GDP growth rate on ROA. Furthermore, the firm characteristics showed that firm size, liquidity and leverage were significant. Ali (2015) found that ROA and ROE were significantly affected by Asset Management, Assets Size, Liquidity, Asset Quality, Deposit, Operating Efficiency, Gearing Ratio, and Financial Risk (internal determinants) while (external determinants) Inflation and GDP are insignificantly affected the bank's profitability. Therefore, we propose that

$\mathrm{H} 2=$ Inflation has impact on ROA of Conventional Banks

\subsubsection{Relationship of Liquidity and bank's performance}

The liquidity of bank is calculated by the proportion of liquid assets. This proportion demonstrates the ability of bank to meet the payments as and when its investors and different providers of funds require. The lower proportion will put the bank in trouble in gathering payments in ideal time and subsequently its liquidity low. The lower proportion would imply that the bank will not easily get reserves or else it should bring about an incredibly high premium rate which will rise the expense of subsidizing and negatively affect the profitability. A very higher proportion will show the abundance of inactive liquid assets. Therefore, higher proportion level forecast the sign of troublesome, and consequently proper investigation takes place (Rao \& Lakew, 2012). Curak, Poposki and Pepur (2012) analyzes the industry-specific, bank-specific and macroeconomic determinants of profitability with a sample of 16 banks in the Macedonian banking system over the period 2005-2010. They found that liquidity risk, operating expense, and solvency risk have significant negative affect on ROA. Vieira (2010) found the insignificant positive association between profitability and liquidity in the short run. Petria, 
Capraru and Ihnatov (2015) investigated the main determinants of bank's profitability in EU27 over the period 2004-2011. They selected panel level fixed effects to conclude the result and found that management efficiency, credit, liquidity risk, the diversification of business and the economic growth have effect on bank's profitability, both on ROAE and ROAA. They also found positive affect of competition on bank's profitability. Albulescu and Ionescu (2018) conducted a study in which they have focused on the internal determinants of the banks' profitability in South and Central American countries and performed panel data analysis. They found that the liquidity, bank capitalization and interest rate margins have positive impact on the profitability of the banks, while the non-interest expense and nonperforming loans have a negative impact on profitability.

Hence, we propose that

H3= Liquidity has impact on ROA of Conventional Banks

\subsubsection{Relationship of Size and bank's performance}

Boyd and Runkle (1993) indicated that the size of a bank is frequently connected with the idea of economies of scale. It is clarified in "Economic Theory" that if an industry is exposed to economies of scale, the firm could be increasingly proficient to deliver at low cost. It is normal that bank size or economies of scale is identified positively with the profitability. To contrast large banks and little banks, large banks are expected to appreciate economies of scale, they can deliver huge number of items economically and productively. In this manner, huge banks are ready to produce higher rate of return as compare to little banks. Furthermore, Antoun, Coskun, and Georgiezski (2018) conducted a study to investigate the industry-specific, bank-specific, and macroeconomic determinants of the financial performance of banks in Eastern and Central European Countries over the period 2009-2014. They used fixed-effect panel regression method and found that the earnings of banks and asset quality are affected negatively by the size, and affected positively by the inflation and business mix. Akhtar, Ali and Sadaqat (2011) examined the profitability of commercial banks over the period 2006-2009 in Pakistan and found that NPLs ratio, gearing ratio and asset management have significant effect on the profitability of commercial banks.

So, we propose that

$\mathrm{H} 4=$ Size has impact on ROA of Conventional Banks

\subsubsection{Relationship of Capital Adequacy and bank's performance}

Capital adequacy ratio is an essential proportion to decide the strength of the capital. It is determined as the ratio of equity to total assets of the Company (Abel \& Le Roux, 2016)\&(Anbar \& Alper, 2011). A positive association was found between the capital adequacy and profitability of the commercial banks (Ebenezer, Omar, \& Kamil, 2017). Alshatti (2016) examined the basic determinants that influenced the profitability of the commercial banks over the period 2005-2014, by applying a balanced panel data set of 13 banks in Jordan. He found that the determinants of Capital adequacy, Leverage and Capitalization positively affect the productivity of banks as estimated by ROA. Furthermore, there is a positive outcome of Capitalization and Leverage when estimated by ROE. In the same way, Antoun et al. (2018) stated that liquidity and capital adequacy are negatively affected by size and positively affected by economic growth and bank concentration. The result analyzed that independent variables i.e. Funding Costing, Nonperforming loans, Liquidity, and Administrative expenses negatively affected the ROA, while positively affected by Non-fund based services, GDP and Capital Adequacy (Nisar, Susheng, Jaleel, \& Ke, 2015). Mohiuddin (2017) conducted a study in Bangladesh over the period of 2009-2012 and found that spread ratio, non-interest income and profit per employee have positive relationship, but operating expenses ratio and capital adequacy have considerable negative association with ROA.

So, we propose that

H5= Capital Adequacy has impact on ROA of Conventional Bank 


\section{Research Methodology and Conceptual Framework 3.1 Conceptual Framework}

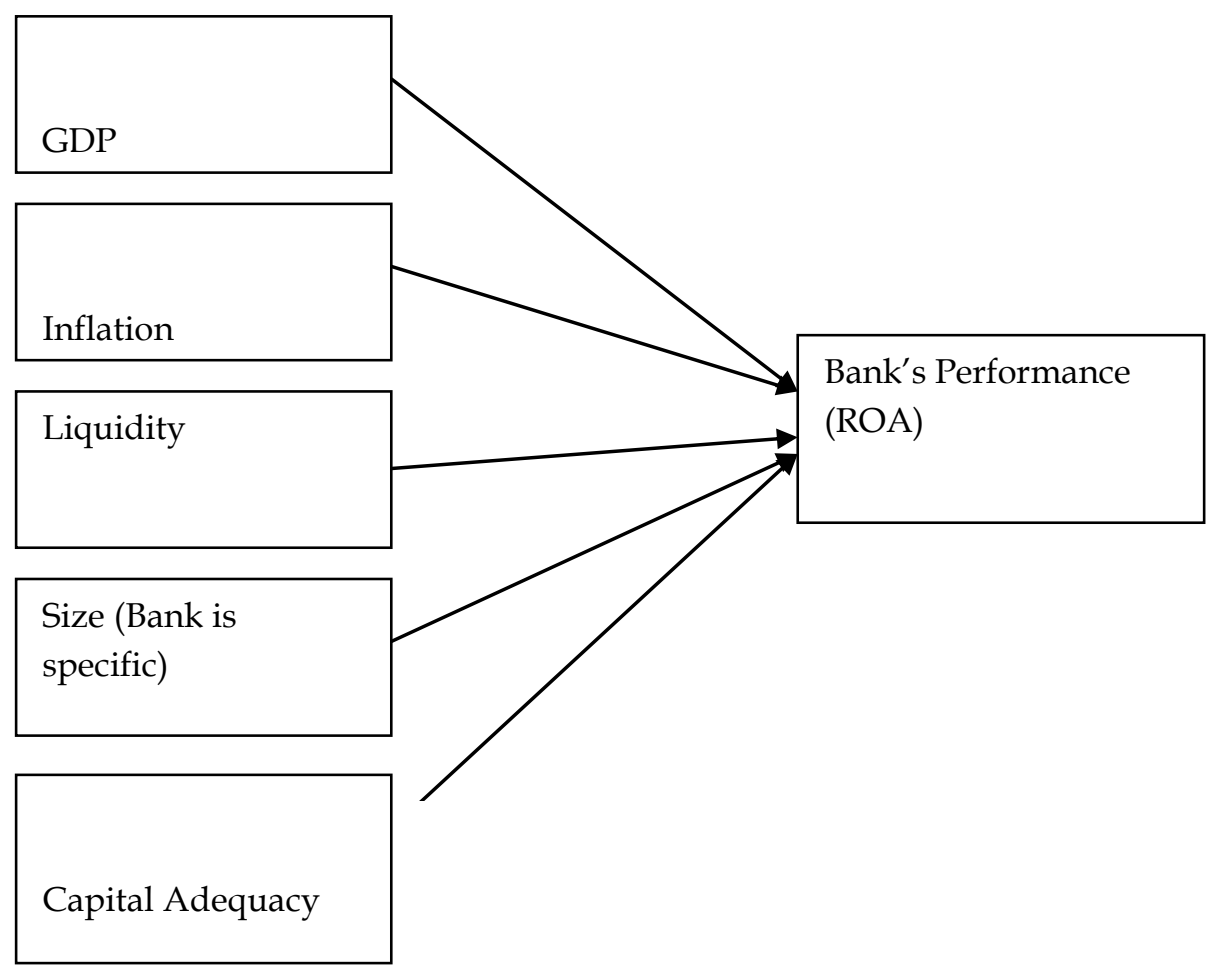

Figure 1. Conceptual Framework

\subsection{Resealul nvelluuulugy}

\subsubsection{Research design}

The research design of this study is quantitative based on post positivist paradigm. Independent variables of the study are inflation, GDP, Capital Adequacy, liquidity and firm size, whereas dependent variables are bank's performance which is represented as ROA i.e. Return on Assets.

\subsubsection{Data Source}

The information of monetary factors (dependent and independent factors) are gathered from auxiliary sources which incorporate State Bank of Pakistan Reports, distributed Final Reports or fiscal summaries of banks on their websites, Pakistan Statistics Bureau reports and Economic Survey of Pakistan reports.

\subsubsection{Target Population}

Currently, there are 22 commercial banks. Out of which, we have taken seventeen listed conventional banks into the sample for this study. They are:

Askari Commercial Bank Limited (AKBL)

National Bank of Pakistan (NBP)

MCB Bank Ltd $\quad$ (MCB)

Habib Bank Ltd (HBL)

Habib Metro Bank Ltd $\quad$ (HMB)

Summit Bank (SMBL)

JS Bank Limited (JSBL)

Bank of Khyber Limited (BOK)

Faysal Bank Ltd (FABL)

SAMBA Bank Limited. (SBL)

Allied Bank Limited (ABL) 
Bank Alfalah Limited

United Bank Limited

Bank of Punjab Limited

Bank Al Habib Limited

Soneri Bank Limited

Standard Chartered Bank
(BAFL)

(UBL)

(BOP)

(BAHL)

(SNBL)

(SCBPL)

\subsubsection{Sample Size}

The sample size consists of the panel data of seventeen conventional banks, over the period of five years, (2013-17). There were 85 observations for testing to make our research accurate.

\subsubsection{Sampling Technique}

The judgmental sample technique was used for gathering the data to test the hypothesis and in analyzing the data of conventional banks.

\subsubsection{Research Model}

Bank's Performance $=$ Bo + B1GDP + B2INF + B3LQ+B4SZ+B5CAR $+\sigma$

Where,

$$
\begin{aligned}
& \text { GDP = Gross Domestic Product } \\
& \text { INF = Inflation } \\
& \text { LQ = Liquidity of conventional banks } \\
& \text { SZ = Size of conventional banks } \\
& \text { CAR = Capital Adequacy } \\
& \sigma=\text { Error }
\end{aligned}
$$

\subsubsection{Transformation of Variables}

This study utilized the log variable change condition to satisfy the supposition of panel regression analysis. It is one of the significant solutions for dispose of heteroscedasticity issue in the data of panel analysis.

\section{Data Analysis and Discussion}

In this study, we used Eviews9 for statistical analysis, as it is robust software for analyzing the economic data. Furthermore, we used Tobin's $Q$ to provide the investors more accurate and effective information for their decision-making process.

\subsection{Data Analysis}

\subsubsection{Regression Analysis}

Table 1. OLS Regression

\begin{tabular}{|l|l|l|l|l|}
\hline Variable & Coefficient & Std. Error & t-Statistic & Prob. \\
\hline C & 2.804569 & 2.214076 & 1.266700 & 0.2090 \\
\hline LNLQ & -0.484722 & 0.334741 & -1.448051 & 0.1516 \\
\hline LNCAR & 0.786242 & 0.297838 & 2.639833 & 0.0100 \\
\hline LNINF & 0.389536 & 0.249881 & 1.558886 & 0.1230 \\
\hline LNGDP & -3.731574 & 1.157347 & -3.224248 & 0.0018 \\
\hline LNASS & 0.259757 & 0.072510 & 3.582385 & 0.0006 \\
\hline R-squared & 0.455125 & Mean dependent var & 0.996588 \\
\hline Adjusted R-squared & 0.420639 & \multicolumn{2}{l}{ S.D. dependent var } & 0.710199 \\
\hline S.E. of regression & 0.540573 & Akaike info criterion & 1.675599 \\
\hline
\end{tabular}




\begin{tabular}{|l|l|l|l|}
\hline Sum squared resid & 23.08532 & Schwarz criterion & 1.848022 \\
\hline Log likelihood & -65.21298 & Hannan-Quinn criter. & 1.744953 \\
\hline F-statistic & 13.19748 & Durbin-Watson stat & 0.749535 \\
\hline Prob(F-statistic) & 0.000000 & & \\
\hline
\end{tabular}

Table 1 provides the OLS regression of the given model. In the given case, the value of probability (F-statistics) is $>0.05$ which indicate that the overall model is right. The adjusted $\mathrm{R}^{2}$ value showed that explanatory power is $42 \%$. The $t$ statistics and its probability show the significance of individual variable. According to the given analysis, the liquidity has insignificant impact on ROA $(p>0.05)$. Capital adequacy ratio has significant positive affect on ROA $(\mathrm{t}=2.6 . \mathrm{p}<0.05)$. Inflation has insignificant impact on ROA $(t=1.5, p>0.05)$. GDP is significantly but negatively associated with ROA $(t=-3.22, p<0.05)$ and size has positively significant impact on $\mathrm{ROA}(\mathrm{t}=3.5, \mathrm{p}<0.05)$.

\subsubsection{Hausman Test}

Hausman test is used to find the best method between the random effect and fixed effect. The value of $P$ is greater than 0.05 . Hence, it is suggested that random effect model is more suitable than fixed effect model.

Table 2. Hausman Test

Correlated Random Effects - Hausman Test

\begin{tabular}{|l|l|l|l|}
\hline & Chi-Sq. Statistic & Chi-Sq. d.f. & Prob. \\
\hline Test Summary & & & 1.0000 \\
\hline
\end{tabular}

${ }^{*}$ Cross-section test variance is invalid. Hausman statistic set to zero.

\subsubsection{Stock Performance (Tobin's Q)}

In financial aspects, the greater value of Tobin's $Q$ from 1 show that firm is worthier than its stated cost of assets. It shows that the profits made by the firm will be greater than the cost of firm's asset. Therefore, additional investment in the firm will be made sense. In another case, the lower value of Tobin's $Q$ from 1 means that market value is lower than its stated value of assets which ultimately means that it will be cost more when replacing the firm's assets than the firm's actual worth of assets. Hence, it is better for firm to sell its assets rather than to put assets in use. The ideal state will be when the firm will be in equilibrium state when Tobin's Q ratio is equal to the one (Bond \& Cummins, 2004).

Tobin's Q is usually calculated as Market value / Total Assets value and the common practice is also to assume equivalence of the liabilities market and book value yielding. So,

Tobin's Q = Equity market value+ Liabilities Book value/ Equity book value+ Liabilities Book value Where, Equity market value $=$ Market price per share* total number of shares

And Equity book value $=$ Total Assets-Total liabilities

\subsubsection{Discriminate Zone}

Tobin's $Q>1$ explains that the stock is overvalued. It shows that stock is expensive as compare to the cost of assets.

Tobin's $Q<1$ explains that the stock is undervalued. It shows that market value is less than the cost of assets.

Tobin's Q=1 denotes fairness of stock value. Hence, market value is reflected exclusively as the cost of assets.

\subsection{Discussions}

\subsubsection{Relationship of Liquidity and bank's performance}

This study found an insignificant negative effect of liquidity on ROA. Results are consistent with various studies (Eichengreen \& Gibson, 2001 ; Bourke, 1989 Molyneux \& Thornton, 1992 \&Goddard, 
Molyneux, \& Wilson, 2004). Similarly, Idris et al. (2011) analyzed the determinants of the profitability of nine Islamic banking institutions in Malaysia. The researchers found no association between the liquidity and the profitability of Malaysian banks. On the other hand, the result is found inconsistent with the findings of Haron (2004) that empirically validate a positive relationship between liquidity and profitability. According to Eichengreen and Gibson (2001), we might expect the greater profitability with the tied up of smaller amount of funds in liquid investments. Therefore, it is extremely easy to understand the inverse relationship association between the liquidity and profitability.

\subsubsection{Relationship of Size and bank's performance}

This study found that bank size has significant positive impact on profitability. The research findings of (Wasiuzzaman \& Tarmizi, 2010 ; Bashir, 2003) was found consistent with the significant positive affect on profitability of banks. However, the research conducted by (Pasiouras \& Kosmidou, 2007 ; Hassan Al-Tamimi, 2006 ; Srairi, 2010 \&Athanasoglou, Brissimis, \& Delis, 2008) provide inconsistent results.

\subsubsection{Relationship of capital adequacy ratio and bank's performance}

This study found that capital adequacy ratio has positive and significant impact on profitability. Capital adequacy play a vital role in the financial institutions of developing countries, because it provides more strength and increase safety for depositors in bad macroeconomic circumstances (Sufian, 2009 ;Trujillo-Ponce, 2013 ; Anbar \& Alper, 2011). If more assets are created with the capital, interest expense will be decrease and profitability will be increase(Molyneux \& Thornton, 1992). The results are widely supported and consistent with previous studies that banks become more stable, profitable and are able to deal with financial stresses and losses (Sufian, 2009; ; Trujillo-Ponce, 2013 ; Athanasoglou Panayiotis, 2008 ; Anbar \& Alper, 2011 ; Zhang \& Daly, 2013).

\subsubsection{Relationship of GDP and bank's performance}

The study found that GDP has significant negative impact on the profitability of conventional banks of Pakistan. Pakistan is suffering from various economic crisis. Therefore, much time is needed to decrease the shocks of the economy. Therefore, the results exhibit the negative impact of GDP on profitability. Also, we have seen that there is not much variation found in Gross Domestic Product (GDP) in the last ten years. Therefore, it is negatively associated to their profitability. The result is found consistent with the research conclusion of the study conducted by Sufian (2011).

\subsubsection{Tobin's $Q$ results}

According to the calculations of Tobin's $Q$, it is found that the Tobin's $Q$ value of banks AKBL, NBP, HBL, HMB, SMBL, JSBL, BOK, ABL, UBL, BAHL, SNBL is increasing gradually and moving from under value to equilibrium and approximately nearer to one. The ratio of MCB bank is devalued in the years 2014-2017 but increased in the year 2018. Ratio of bank SCBPL is undervalued in trending years but increasing gradually. The ratios of banks FABL, BOP, BAFL decreasing gradually in years of analysis, but nearer to one. The ratio of bank SBL is drastically devaluing in year's analysis. The stock is going from overvalue towards under value which shows bad situation for this bank. It is to be considered that the average value of Tobin's $Q$ of many banks is in equilibrium position. The investors must look towards certain stock market conditions and can sale the shares of banks whose prices are undervalued.

\section{Conclusion \& Recommendations}

The purpose of this study is to analyze the impact of macroeconomic and financial indicators on determinants of profitability of conventional banks in Pakistan. This study is an endeavor to assist the investors by providing them information on the current stock market situation through which they can invest in the future or sells shares from the unwanted banks. The study shows the stock value of most conventional banks is moving from undervalue to overvalue. Hence, the Government should take the proper initiatives to enhance the confidence of investors towards the stock market. Researchers can expand this research by analyzing the impact of financial and economic indicators on profitability on Islamic banking. Furthermore, they can include more variables to analyze their effect on profitability of the banking sector. The researchers can also calculate the Tobin's $Q$ ratio by taking Islamic banks of Pakistan. 


\section{References}

Abel, S., \& Le Roux, P. (2016). Assessing Banking Sector Competition in Zimbabwe Using a Panzar-Rosse Approach. Economic Research Southern Africa, ERSA Working Paper No. 599.

Abidi, F. S., \& Lodhi, S. (2015). Impact of changes in reserve requirement on banks profitability: A case of commercial banks in Pakistan. European Journal of Business and Management, 1-6.

Ahmad, S., Nafees, B., \& Khan, Z. A. (2012). Determinants of profitability of Pakistani banks: Panel data evidence for the period 2001-2010. Journal of Business Studies Quarterly, 4(1), 149-156.

Akhtar, M. F., Ali, K., \& Sadaqat, S. (2011). Factors influencing the profitability of Islamic banks of Pakistan. International Research Journal of Finance and Economics, 1-8.

Ali, M. (2015). Bank profitability and its determinants in Pakistan: A panel data analysis after financial crisis. MPRA Paper No. 67987.

Alshatti, A. S. (2016). Determinants of banks' profitability- the case of Jordan.Investment Management and Financial Innovations, 13(1), 84-91.

Anbar, A., \& Alper, D. (2011). Bank specific and macroeconomic determinants of commercial bank profitability: Empirical evidence from Turkey. Business and Economics Research Journal, 2(2), 139-152.

Antoun, R., Coskun, A., \& Georgiezski, B. (2018). Determinants of financialperformance of banks in Central and Eastern Europe. Business and Economic Horizons, 513-529.

Anwar, Y. (2011). Role of Financial Institutions and Capital Market in Pakistan's Economy. Governor's Speeches.

Athanasoglou, P. P., Brissimis, S. N., \& Delis, M. D. (2008). Bank-specific, industry-specific and macroeconomic determinants of bank profitability. Journal of International Financial Markets, Institutions and Money, 18(2), 121-136.

Bashir, A.-H. M. (2003). Determinants of profitability in Islamic banks: Some evidence from the Middle East. Islamic Economic Studies, 31-57.

Bourke, P. (1989). Concentration and other determinants of bank profitability in Europe, North America and Australia. Journal of Banking \& Finance, 13(1), 65-79.

Curak, M., Poposki, K., \& Pepur, S. (2012). Profitability determinants of the Macedonian banking sector in changing environment. Procedia-Social and Behavioral Sciences, 406-416.

Dubelaar, C., Sohal, A., \& Savic, V. (2005). Benefits, impediments and critical success factors in B2C E-business adoption. Technovation, 25(11), 1251-1262.

Ebenezer, O. O., Omar, W. A. W. B., \& Kamil, S. (2017). Bank specific and macroeconomic determinants of commercial bank profitability: Empirical evidence from Nigeria. International Journal of Finance \& Banking Studies, 6(1), 25-38.

Egbunike, C. F., \& Okerekeoti, C. U. (2018). Macroeconomic factors, firm characteristics and financial performance: A study of selected quoted manufacturing firms in Nigeria. Asian Journal of Accounting Research, 3(2), $142-168$.

Eichengreen, B., \& Gibson, H. D. (2001). Greek banking at the dawn of the new millennium. working paper no. 2791.

Fani, K.A., Khan.V. J., Kumar, B., \& Kumar, B. (2018). Impact of Internal and External Factors on Bank Performance in Pakistan. International and Public Affairs, 66-77.

Haron, S. (2004). Determinants of Islamic bank profitability. Global Journal of Finance and Economics, 1(1), 11-33.

Hassan Al-Tamimi, H. A. (2006). The determinants of the UAE commercial banks' performance: A comparison of the national and foreign banks. Journal of Transnational Management, 10(4), 35-47.

Idris, A.R., F.F.A.H. Asari, N.A.A. Taufik, N.J. Salim, R. Mustaffa and K. Jusoff, 2011. (2011). Determinant of Islamic banking institutions' profitability in Malaysia. World Appl. Sci. J, 01-07.

Johnson, Z., \& Sammer, M. (2016). Determinants of profitability in Banking Sector. International Journal of Information Research and Review, 2258-2264.

Kamran, Hafiz Waqas, Zermen Johnson, and Mamoona Sammer. 2016. Determinants of Profitability in Banking Sector. International Journal of Information Research and Review, 2258-2264.

Levine, R., Loayza, N., \& Beck, T. (2000). Financial intermediation and growth: Causality and causes. Journal of Monetary Economics, 46(1), 31-77.

Mohiuddin, M. (2017). The Determinants of Profitability of Private Banks in Bangladesh: An Empirical Analysis. Igdir University Journal of Social Sciences, 141-172.

Molyneux, P., \& Thornton, J. (1992). Determinants of European bank profitability: A note. Journal of Banking \& Finance, 16(6), 1173-1178.

Nisar, S., Susheng, W., Jaleel, A., \& Ke, P. (2015). Determinants of bank's profitability in Pakistan: A latest panel data evidence. International Journal of Economics, Commerce and Management, 1-20.

Pasiouras, F., \& Kosmidou, K. (2007). Factors influencing the profitability of domestic and foreign commercial banks in the European Union. Research in International Business and Finance, 222-237.

Petria, N., Capraru, B., \& Ihnatov, I. (2015). Determinants of banks' profitability: Evidence from EU 27 banking systems. Procedia Economics and Finance, 518-524. 
Rao, K. R. M., \& Lakew, T. B. (2012). Cost Efficiency and Ownership Structure of Commercial Banks in Ethiopia: An application of non-parametric approach. European Journal of Business and Management, 4(10), 36-47.

Rashid, A., \& Jabeen, S. (2016). Analyzing performance determinants: Conventional versus Islamic banks in Pakistan. Borsa Istanbul Review, 16(2), 92-107.

Srairi, S. A. (2010). Cost and profit efficiency of conventional and Islamic banks in GCC countries. Journal of Productivity Analysis, 34(1), 45-62.

Sufian, F. (2009). Determinants of bank profitability in a developing economy: Empirical evidence from the China banking sector. Journal of Asia-Pacific Business, 10(4), 281-307.

Trujillo-Ponce, A. (2013). What determines the profitability of banks? Evidence from Spain. Accounting \& Finance, 53(2), 561-586.

Vieira, R. (2010). The relationship between liquidity and profitability: An exploratory study of airline companies between 2005 and 2008. (Unpublished master thesis), Umea University.

Wasiuzzaman, S., \& Tarmizi, H. (2010). Profitability of Islamic banks in Malaysia: An empirical analysis. Journal of Islamic Economics, Banking and Finance, 6(4), 53-68.

Zhang, X., \& Daly, K. J. (2013). The impact of bank specific and macroeconomic factors on China's bank performance. Global Economy and Finance Journal, 6(2), 1-25.

Zopounidis, C., \& Kosmidou, K. (2008). The determinants of banks' profits in Greece during the period of EU financial integration. Managerial Finance, 146-159.

\section{Appendices}

Data of Conventional Banks of Pakistan (2014-2018)

\begin{tabular}{|l|l|l|l|l|l|l|l|}
\hline Banks & Year & ROA $\%$ & LQ $\%$ & Size & CAR & INF & GDP \\
\hline AKBL & 2014 & 0.95 & 43.99 & $447,083,000,000$ & 13.03 & 2.9 & 4.6 \\
\hline AKBL & 2015 & 1.03 & 46.16 & $535,867,000,000$ & 12.51 & 4.5 & 4.7 \\
\hline AKBL & 2016 & 0.9 & 49.74 & $619,139,000,000$ & 12.5 & 8.6 & 5.5 \\
\hline AKBL & 2017 & 0.83 & 49.2 & $656,708,000,000$ & 12.09 & 7.4 & 5.7 \\
\hline AKBL & 2018 & 0.65 & 59.81 & $706,532,000,000$ & 12.51 & 3.9 & 5.4 \\
\hline NBP & 2014 & 1.03 & 50.81 & $1,543,054,000,000$ & 18.17 & 2.9 & 4.6 \\
\hline NBP & 2015 & 1.18 & 40.38 & $1,706,361,000,000$ & 17.59 & 4.5 & 4.7 \\
\hline NBP & 2016 & 1.24 & 40.27 & $2,008,855,000,000$ & 16.54 & 8.6 & 5.5 \\
\hline NBP & 2017 & 1.05 & 42.83 & $2,505,321,000,000$ & 15.97 & 7.4 & 5.7 \\
\hline NBP & 2018 & 0.78 & 46.04 & $2,798,566,000,000$ & 18.05 & 3.9 & 5.4 \\
\hline MCB & 2014 & 2.78 & 44.1 & $934,631,000,000$ & 20.41 & 2.9 & 4.6 \\
\hline MCB & 2015 & 2.63 & 43.65 & $1,004,410,000,000$ & 19.43 & 4.5 & 4.7 \\
\hline MCB & 2016 & 2.16 & 44.55 & $1,072,365,000,000$ & 19.33 & 8.6 & 5.5 \\
\hline MCB & 2017 & 1.86 & 48.46 & $1,343,238,000,000$ & 16.44 & 7.4 & 5.7 \\
\hline MCB & 2018 & 1.5 & 48 & $1,498,130,000,000$ & 18 & 3.9 & 5.4 \\
\hline HBL & 2014 & 1.8 & 43.7 & $1,864,618,000,000$ & 16.2 & 2.9 & 4.6 \\
\hline HBL & 2015 & 1.7 & 43.2 & $2,218,433,000,000$ & 17 & 4.5 & 4.7 \\
\hline HBL & 2016 & 1.4 & 43.3 & $2,519,077,000,000$ & 15.5 & 8.6 & 5.5 \\
\hline HBL & 2017 & 0.3 & 46.1 & $2,696,218,000,000$ & 15.96 & 7.4 & 5.7 \\
\hline HBL & 2018 & 0.4 & 53.9 & $3,025,853,000,000$ & 16.18 & 3.9 & 5.4 \\
\hline HMB & 2014 & 1.2 & 42.16 & $409,894,000,000$ & 17.39 & 2.9 & 4.6 \\
\hline HMB & 2015 & 1.52 & 32.94 & $502,433,000,000$ & 18.35 & 4.5 & 4.7 \\
\hline HMB & 2016 & 1.13 & 33.25 & $538,007,000,000$ & 18.34 & 8.6 & 5.5 \\
\hline HMB & 2017 & 0.83 & 34.3 & $660,666,000,000$ & 17.36 & 7.4 & 5.7 \\
\hline HMB & 2018 & 0.91 & 41.7 & $673,396,000,000$ & 16 & 3.9 & 5.4 \\
\hline
\end{tabular}


The Business and Management Review, Volume 11 Number 1

\begin{tabular}{|c|c|c|c|c|c|c|c|}
\hline SMBL & 2014 & 0.15 & 63.1 & $148,457,000,000$ & 12.22 & 2.9 & 4.6 \\
\hline SMBL & 2015 & 0.12 & 58.87 & $188,420,000,000$ & 19.8 & 4.5 & 4.7 \\
\hline SMBL & 2016 & -1.01 & 55.89 & $215,022,000,000$ & 10.1 & 8.6 & 5.5 \\
\hline SMBL & 2017 & -0.49 & 58.69 & $233,050,000,000$ & 5.01 & 7.4 & 5.7 \\
\hline SMBL & 2018 & -1.64 & 61.19 & $199,951,000,000$ & 19 & 3.9 & 5.4 \\
\hline JSBL & 2014 & 0.59 & 57.41 & $176,717,000,000$ & 16.73 & 2.9 & 4.6 \\
\hline JSBL & 2015 & 1.03 & 54.05 & $218,476,000,000$ & 15.23 & 4.5 & 4.7 \\
\hline JSBL & 2016 & 0.86 & 41.48 & $267,444,000,000$ & 15.65 & 8.6 & 5.5 \\
\hline JSBL & 2017 & 0.3 & 63.48 & $391,479,000,000$ & 12.77 & 7.4 & 5.7 \\
\hline JSBL & 2018 & 0.13 & 78.4 & $456,754,000,000$ & 12.8 & 3.9 & 5.4 \\
\hline BOK & 2014 & 1.03 & 43.4 & $126,106,000,000$ & 22.65 & 2.9 & 4.6 \\
\hline $\mathrm{BOK}$ & 2015 & 1.15 & 31.07 & $155,159,000,000$ & 23.75 & 4.5 & 4.7 \\
\hline BOK & 2016 & 0.97 & 20.15 & $206,400,000,000$ & 21.34 & 8.6 & 5.5 \\
\hline $\mathrm{BOK}$ & 2017 & 0.73 & 52.35 & $245,132,000,000$ & 20 & 7.4 & 5.7 \\
\hline $\mathrm{BOK}$ & 2018 & 0.2 & 55.5 & $223,095,000,000$ & 12.28 & 3.9 & 5.4 \\
\hline FABL & 2014 & 0.67 & 66.25 & $388,126,000,000$ & 12.22 & 2.9 & 4.6 \\
\hline FABL & 2015 & 1.03 & 63.25 & $430,073,000,000$ & 14.41 & 4.5 & 4.7 \\
\hline FABL & 2016 & 0.98 & 61.1 & $452,022,000,000$ & 14.62 & 8.6 & 5.5 \\
\hline FABL & 2017 & 0.96 & 61.35 & $494,934,000,000$ & 15.9 & 7.4 & 5.7 \\
\hline FABL & 2018 & 0.88 & 67.6 & $599,914,000,000$ & 16.72 & 3.9 & 5.4 \\
\hline SBL & 2014 & 0.5 & 68.9 & $50,581,000,000$ & 9.14 & 2.9 & 4.6 \\
\hline SBL & 2015 & 0.6 & 62.3 & $80,166,000,000$ & 13.84 & 4.5 & 4.7 \\
\hline SBL & 2016 & 0.6 & 57.2 & $103,100,000,000$ & 10.67 & 8.6 & 5.5 \\
\hline SBL & 2017 & 0.6 & 73.2 & $118,224,000,000$ & 10.94 & 7.4 & 5.7 \\
\hline SBL & 2018 & 0.6 & 82.2 & $122,765,000,000$ & 10.92 & 3.9 & 5.4 \\
\hline $\mathrm{ABL}$ & 2014 & 1.78 & 45.82 & $842,269,000,000$ & 19.88 & 2.9 & 4.6 \\
\hline $\mathrm{ABL}$ & 2015 & 1.52 & 43.78 & $991,665,000,000$ & 21 & 4.5 & 4.7 \\
\hline ABL & 2016 & 1.34 & 41.02 & $1,069,615,000,000$ & 20.88 & 8.6 & 5.5 \\
\hline ABL & 2017 & 1.01 & 42.09 & $1,249,665,000,000$ & 22.38 & 7.4 & 5.7 \\
\hline $\mathrm{ABL}$ & 2018 & 0.95 & 44.52 & $1,350,606,000,000$ & 22.05 & 3.9 & 5.4 \\
\hline UBL & 2014 & 2.1 & 46.2 & $1,111,414,000,000$ & 13.9 & 2.9 & 4.6 \\
\hline UBL & 2015 & 2 & 41.3 & $1,400,651,000,000$ & 14.68 & 4.5 & 4.7 \\
\hline UBL & 2016 & 1.8 & 42.1 & $1,600,632,000,000$ & 14.88 & 8.6 & 5.5 \\
\hline UBL & 2017 & 1.4 & 46.4 & $2,032,934,000,000$ & 15.11 & 7.4 & 5.7 \\
\hline UBL & 2018 & 0.8 & 48.7 & $1,889,599,000,000$ & 16.98 & 3.9 & 5.4 \\
\hline $\mathrm{BOP}$ & 2014 & 0.66 & 49.75 & $420,370,000,000$ & 10.21 & 2.9 & 4.6 \\
\hline $\mathrm{BOP}$ & 2015 & 1.01 & 58.51 & $472,284,000,000$ & 10.49 & 4.5 & 4.7 \\
\hline $\mathrm{BOP}$ & 2016 & 0.88 & 57.82 & $547,424,000,000$ & 12.28 & 8.6 & 5.5 \\
\hline $\mathrm{BOP}$ & 2017 & -0.5 & 53.16 & $657,737,000,000$ & 9.67 & 7.4 & 5.7 \\
\hline BOP & 2018 & 1.05 & 64.11 & $714,380,000,000$ & 13.01 & 3.9 & 5.4 \\
\hline BAFL & 2014 & 0.83 & 48.15 & $755,902,000,000$ & 12.75 & 2.9 & 4.6 \\
\hline BAFL & 2015 & 0.93 & 52.19 & $918,404,000,000$ & 13.27 & 4.5 & 4.7 \\
\hline
\end{tabular}




\begin{tabular}{|l|l|l|l|l|l|l|l|} 
BAFL & 2016 & 0.88 & 59.08 & $929,645,000,000$ & 13.18 & 8.6 & 5.5 \\
\hline BAFL & 2017 & 0.87 & 62.11 & $998,828,000,000$ & 13.39 & 7.4 & 5.7 \\
\hline BAFL & 2018 & 1.11 & 71.36 & $1,006,218,000,000$ & 14.95 & 3.9 & 5.4 \\
\hline BAHL & 2014 & 1.09 & 40.71 & $579,394,000,000$ & 14.89 & 2.9 & 4.6 \\
\hline BAHL & 2015 & 1.15 & 40.15 & $639,973,000,000$ & 13.75 & 4.5 & 4.7 \\
\hline BAHL & 2016 & 1.05 & 44.75 & $768,018,000,000$ & 14.18 & 8.6 & 5.5 \\
\hline BAHL & 2017 & 0.9 & 49.06 & $944,134,000,000$ & 13.87 & 7.4 & 5.7 \\
\hline BAHL & 2018 & 0.8 & 60 & $1,048,239,000,000$ & 13.52 & 3.9 & 5.4 \\
\hline SNBL & 2014 & 0.81 & 66.25 & $216,473,000,000$ & 12.5 & 2.9 & 4.6 \\
\hline SNBL & 2015 & 0.94 & 60.59 & $255,655,000,000$ & 15.39 & 4.5 & 4.7 \\
\hline SNBL & 2016 & 0.7 & 59.7 & $281,805,000,000$ & 14.12 & 8.6 & 5.5 \\
\hline SNBL & 2017 & 0.55 & 72.28 & $325,219,000,000$ & 12.27 & 7.4 & 5.7 \\
\hline SNBL & 2018 & 0.5 & 71.07 & $382,498,000,000$ & 14.7 & 3.9 & 5.4 \\
\hline SCBPL & 2014 & 2.4 & 42.22 & $409,568,000,000$ & 18.91 & 2.9 & 4.6 \\
\hline SCBPL & 2015 & 2.2 & 33.26 & $447,348,000,000$ & 20.32 & 4.5 & 4.7 \\
\hline SCBPL & 2016 & 2.1 & 31.17 & $474,752,000,000$ & 21.04 & 8.6 & 5.5 \\
\hline SCBPL & 2017 & 1.7 & 36.45 & $519,832,000,000$ & 19.27 & 7.4 & 5.7 \\
\hline SCBPL & 2018 & 2.1 & 39.9 & $576,081,000,000$ & 19.09 & 3.9 & 5.4 \\
\hline
\end{tabular}

Calculation of Tobin's $Q$ ratio

\begin{tabular}{|c|c|c|c|c|c|c|c|c|}
\hline Banks & Year & $\begin{array}{l}\text { value } \\
\text { per } \\
\text { share }\end{array}$ & $\begin{array}{l}\begin{array}{l}\text { No. } \\
\text { shares }\end{array} \\
\end{array}$ & $\begin{array}{l}\text { Equity } \\
\text { Market } \\
\text { Value }\end{array}$ & Total Assets & Total Liabilities & $\begin{array}{l}\text { Equity } \\
\text { value }\end{array}$ & $\begin{array}{l}\text { Tobin's } \\
\text { ratio }\end{array}$ \\
\hline \multirow{5}{*}{$\begin{array}{l}\text { AKBL } \\
\text { AKBL } \\
\text { AKBL } \\
\text { AKBL } \\
\text { AKBL }\end{array}$} & 2014 & 23.07 & $6,065,000$ & 139919550 & $447,083,000,000$ & $423,375,000,000$ & $23,708,000,000$ & 0.043346337 \\
\hline & 2015 & 21.74 & $1,762,000$ & 38305880 & $535,867,000,000$ & $509,014,000,000$ & $26,853,000,000$ & 0.04599816 \\
\hline & 2016 & 24.95 & $1,455,000$ & 36302250 & $619,139,000,000$ & $586,562,000,000$ & $32,577,000,000$ & 0.04008016 \\
\hline & 2017 & 19.31 & 307,500 & 5937825 & $656,708,000,000$ & $624,273,000,000$ & $32,435,000,000$ & 0.051786639 \\
\hline & 2018 & 23.92 & 37,000 & 885040 & $706,532,000,000$ & $673,023,000,000$ & $33,509,000,000$ & 0.04180602 \\
\hline \multirow{5}{*}{$\begin{array}{l}\text { NBP } \\
\text { NBP } \\
\text { NBP } \\
\text { NBP } \\
\text { NBP } \\
\end{array}$} & 2014 & 69.46 & $3,303,000$ & 229426380 & $1,543,054,000,000$ & $1,364,725,000,000$ & $178,329,000,000$ & 0.014396775 \\
\hline & 2015 & 54.04 & 99,000 & 5349960 & $1,706,361,000,000$ & $1,538,010,000,000$ & $168,351,000,000$ & 0.018504811 \\
\hline & 2016 & 74.89 & $1,546,500$ & 115817385 & $2,008,855,000,000$ & $1,832,122,000,000$ & $176,733,000,000$ & 0.013352918 \\
\hline & 2017 & 48.56 & $2,796,500$ & 135798040 & $2,505,321,000,000$ & $2,329,939,000,000$ & $175,382,000,000$ & 0.020593081 \\
\hline & 2018 & 42.03 & $5,721,500$ & 240474645 & $2,798,566,000,000$ & $2,591,698,000,000$ & $206,868,000,000$ & 0.023792529 \\
\hline \multirow{5}{*}{$\begin{array}{l}\mathrm{MCB} \\
\mathrm{MCB} \\
\mathrm{MCB} \\
\mathrm{MCB} \\
\mathrm{MCB} \\
\end{array}$} & 2014 & 305.6 & 108,000 & 33004800 & $934,631,000,000$ & $804,527,000,000$ & $130,104,000,000$ & 0.003272251 \\
\hline & 2015 & 216.85 & 82,400 & 17868440 & $1,004,410,000,000$ & $866,608,000,000$ & $137,802,000,000$ & 0.004611483 \\
\hline & 2016 & 237.82 & 387,500 & 92155250 & $1,072,365,000,000$ & $930,739,000,000$ & $141,626,000,000$ & 0.004204861 \\
\hline & 2017 & 212.32 & 620,700 & 131787024 & $1,343,238,000,000$ & $1,189,672,000,000$ & $153,566,000,000$ & 0.004709872 \\
\hline & 2018 & 193.57 & $1,360,700$ & 263390699 & $1,498,130,000,000$ & $1,348,852,000,000$ & $149,278,000,000$ & 0.00516609 \\
\hline \multirow{5}{*}{$\begin{array}{l}\text { HBL } \\
\text { HBL } \\
\text { HBL } \\
\text { HBL } \\
\text { HBL } \\
\end{array}$} & 2014 & 212.26 & 28,700 & 6091862 & $1,864,618,000,000$ & $1,695,022,000,000$ & $169,596,000,000$ & 0.004711203 \\
\hline & 2015 & 200.12 & 779,200 & 155933504 & $2,218,433,000,000$ & $2,035,802,000,000$ & $182,631,000,000$ & 0.004997002 \\
\hline & 2016 & 273.25 & 859,300 & 234803725 & $2,519,077,000,000$ & $2,322,808,000,000$ & $196,269,000,000$ & 0.003659652 \\
\hline & 2017 & 167.09 & $1,029,400$ & 172002446 & $2,696,218,000,000$ & $2,507,467,000,000$ & $188,751,000,000$ & 0.005984799 \\
\hline & 2018 & 120.45 & $2,761,000$ & 332562450 & $3,025,853,000,000$ & $2,826,600,000,000$ & $199,253,000,000$ & 0.0083022 \\
\hline \multirow{2}{*}{$\begin{array}{l}\text { HMB } \\
\text { HMB }\end{array}$} & 2014 & 37.3 & 794,000 & 29616200 & $409,894,000,000$ & $362,629,000,000$ & $47,265,000,000$ & 0.026809651 \\
\hline & 2015 & 30.47 & 235,500 & 7175685 & $502,433,000,000$ & $453,051,000,000$ & $49,382,000,000$ & 0.032819166 \\
\hline
\end{tabular}




\begin{tabular}{|c|c|c|c|c|c|c|c|c|}
\hline \multirow{3}{*}{$\begin{array}{l}\text { HMB } \\
\text { HMB } \\
\text { HMB } \\
\end{array}$} & 2016 & 37 & 40,500 & 1498500 & $538,007,000,000$ & $486,935,000,000$ & $51,072,000,000$ & 0.027027027 \\
\hline & 2017 & 34.5 & 39,500 & 1362750 & $660,666,000,000$ & $620,167,000,000$ & $40,499,000,000$ & 0.028985507 \\
\hline & 2018 & 45.81 & $3,034,500$ & 139010445 & $673,396,000,000$ & $636,393,000,000$ & $37,003,000,000$ & 0.021829295 \\
\hline \multirow{5}{*}{$\begin{array}{l}\text { SMBL } \\
\text { SMBL } \\
\text { SMBL } \\
\text { SMBL } \\
\text { SMBL }\end{array}$} & 2014 & 4.45 & $1,215,500$ & 5408975 & $148,457,000,000$ & $136,095,000,000$ & $12,362,000,000$ & 0.224719101 \\
\hline & 2015 & 3.93 & 105,500 & 414615 & $188,420,000,000$ & $176,462,000,000$ & $11,958,000,000$ & 0.254452926 \\
\hline & 2016 & 4.4 & $3,195,000$ & 14058000 & $215,022,000,000$ & $202,350,000,000$ & $12,672,000,000$ & 0.227272727 \\
\hline & 2017 & 2.77 & $6,503,000$ & 18013310 & $233,050,000,000$ & $222,015,000,000$ & $11,035,000,000$ & 0.36101083 \\
\hline & 2018 & 0.82 & 39,500 & 32390 & $199,951,000,000$ & $189,147,000,000$ & $10,804,000,000$ & 1.219512195 \\
\hline \multirow{5}{*}{$\begin{array}{l}\text { JSBL } \\
\text { JSBL } \\
\text { JSBL } \\
\text { JSBL } \\
\text { JSBL }\end{array}$} & 2014 & 7.14 & 134,500 & 960330 & $176,717,000,000$ & $163,637,000,000$ & $13,080,000,000$ & 0.140056022 \\
\hline & 2015 & 7.75 & 12,500 & 96875 & $218,476,000,000$ & $202,508,000,000$ & $15,968,000,000$ & 0.129032258 \\
\hline & 2016 & 10.81 & $7,006,000$ & 75734860 & $267,444,000,000$ & $250,794,000,000$ & $16,650,000,000$ & 0.092506938 \\
\hline & 2017 & 7.52 & 743,500 & 5591120 & $391,479,000,000$ & $374,810,000,000$ & $16,669,000,000$ & 0.132978723 \\
\hline & 2018 & 7.37 & 290,000 & 2137300 & $456,754,000,000$ & $441,137,000,000$ & $15,617,000,000$ & 0.13568521 \\
\hline \multirow{5}{*}{$\begin{array}{l}\text { BOK } \\
\text { BOK } \\
\text { BOK } \\
\text { BOK } \\
\text { BOK } \\
\end{array}$} & 2014 & 9.85 & 26,500 & 261025 & $126,106,000,000$ & $111,186,000,000$ & $14,920,000,000$ & 0.101522843 \\
\hline & 2015 & 11.26 & 75,000 & 844500 & $155,159,000,000$ & $139,241,000,000$ & $15,918,000,000$ & 0.088809947 \\
\hline & 2016 & 16.55 & 43,000 & 711650 & $206,400,000,000$ & $190,257,000,000$ & $16,143,000,000$ & 0.060422961 \\
\hline & 2017 & 13.5 & 2,500 & 33750 & $245,132,000,000$ & $229,734,000,000$ & $15,398,000,000$ & 0.074074074 \\
\hline & 2018 & 12.95 & 24,500 & 317275 & $223,095,000,000$ & $211,390,000,000$ & $11,705,000,000$ & 0.077220077 \\
\hline \multirow{5}{*}{$\begin{array}{l}\text { FABL } \\
\text { FABL } \\
\text { FABL } \\
\text { FABL } \\
\text { FABL }\end{array}$} & 2014 & 18.2 & $3,836,500$ & 69824300 & $388,126,000,000$ & $361,825,000,000$ & $26,301,000,000$ & 0.054945055 \\
\hline & 2015 & 15.43 & 117,000 & 1805310 & $430,073,000,000$ & $399,720,000,000$ & $30,353,000,000$ & 0.064808814 \\
\hline & 2016 & 21.78 & $1,088,500$ & 23707530 & $452,022,000,000$ & $417,015,000,000$ & $35,007,000,000$ & 0.045913682 \\
\hline & 2017 & 21.26 & 7,500 & 159450 & $494,934,000,000$ & $455,688,000,000$ & $39,246,000,000$ & 0.047036689 \\
\hline & 2018 & 24.07 & $3,429,500$ & 82548065 & $599,914,000,000$ & $556,416,000,000$ & $43,498,000,000$ & 0.041545492 \\
\hline \multirow{5}{*}{$\begin{array}{l}\text { SBL } \\
\text { SBL } \\
\text { SBL } \\
\text { SBL } \\
\text { SBL }\end{array}$} & 2014 & 7 & 196,000 & 1372000 & $50,581,000,000$ & $109,981,000,000$ & $-59,400,000,000$ & 0.142857143 \\
\hline & 2015 & 6 & 10,000 & 60000 & $80,166,000,000$ & $105,515,000,000$ & $-25,349,000,000$ & 0.1666666667 \\
\hline & 2016 & 7.26 & 1,500 & 10890 & $103,100,000,000$ & $90,780,000,000$ & $12,320,000,000$ & 0.137741047 \\
\hline & 2017 & 6.96 & 5,000 & 34800 & $118,224,000,000$ & $68,322,000,000$ & $49,902,000,000$ & 0.143678161 \\
\hline & 2018 & 8.04 & 34,500 & 277380 & $122,765,000,000$ & $39,326,000,000$ & $83,439,000,000$ & 0.124378109 \\
\hline \multirow{5}{*}{$\begin{array}{l}\mathrm{ABL} \\
\mathrm{ABL} \\
\mathrm{ABL} \\
\mathrm{ABL} \\
\mathrm{ABL}\end{array}$} & 2014 & 113.58 & $1,261,400$ & 143269812 & $842,269,000,000$ & $761,379,000,000$ & $80,890,000,000$ & 0.008804367 \\
\hline & 2015 & 94.26 & 16,000 & 1508160 & $991,665,000,000$ & $902,409,000,000$ & $89,256,000,000$ & 0.010608954 \\
\hline & 2016 & 119.21 & 43,000 & 5126030 & $1,069,615,000,000$ & $968,941,000,000$ & $100,674,000,000$ & 0.008388558 \\
\hline & 2017 & 84.98 & $1,136,000$ & 96537280 & $1,249,665,000,000$ & $1,142,949,000,000$ & $106,716,000,000$ & 0.011767475 \\
\hline & 2018 & 107.47 & 524,000 & 56314280 & $1,350,606,000,000$ & $1,243,301,000,000$ & $107,305,000,000$ & 0.009304922 \\
\hline \multirow{5}{*}{$\begin{array}{l}\text { UBL } \\
\text { UBL } \\
\text { UBL } \\
\text { UBL } \\
\text { UBL }\end{array}$} & 2014 & 176.71 & $1,740,500$ & 307563755 & $1,111,414,000,000$ & $985,898,000,000$ & $125,516,000,000$ & 0.005658989 \\
\hline & 2015 & 154.95 & 809,800 & 125478510 & $1,400,651,000,000$ & $1,258,516,000,000$ & $142,135,000,000$ & 0.006453695 \\
\hline & 2016 & 238.9 & 882,900 & 210924810 & $1,600,632,000,000$ & $1,448,845,000,000$ & $151,787,000,000$ & 0.004185852 \\
\hline & 2017 & 187.97 & $1,329,800$ & 249962506 & $2,032,934,000,000$ & $1,873,627,000,000$ & $159,307,000,000$ & 0.005319998 \\
\hline & 2018 & 122.64 & $12,632,400$ & 1549237536 & $1,889,599,000,000$ & $1,738,329,000,000$ & $151,270,000,000$ & 0.008153947 \\
\hline \multirow{5}{*}{$\begin{array}{l}\text { BOP } \\
\text { BOP } \\
\text { BOP } \\
\text { BOP } \\
\text { BOP }\end{array}$} & 2014 & 10.95 & $7,556,000$ & 82738200 & $420,370,000,000$ & $401,043,000,000$ & $19,327,000,000$ & 0.091324201 \\
\hline & 2015 & 9.21 & $2,824,000$ & 26009040 & $472,284,000,000$ & $449,605,000,000$ & $22,679,000,000$ & 0.108577633 \\
\hline & 2016 & 17.65 & $38,084,500$ & 672191425 & $547,424,000,000$ & $519,569,000,000$ & $27,855,000,000$ & 0.056657224 \\
\hline & 2017 & 8.24 & $6,655,000$ & 54837200 & $657,737,000,000$ & $628,005,000,000$ & $29,732,000,000$ & 0.121359223 \\
\hline & 2018 & 11.97 & $10,006,500$ & 119777805 & $714,380,000,000$ & $676,659,000,000$ & $37,721,000,000$ & 0.083542189 \\
\hline \multirow{4}{*}{$\begin{array}{l}\text { BAFL } \\
\text { BAFL } \\
\text { BAFL } \\
\text { BAFL }\end{array}$} & 2014 & 34.88 & $8,390,500$ & 292660640 & $755,902,000,000$ & $711,083,000,000$ & $44,819,000,000$ & 0.028669725 \\
\hline & 2015 & 28.82 & 441,000 & 12709620 & $918,404,000,000$ & $865,051,000,000$ & $53,353,000,000$ & 0.034698126 \\
\hline & 2016 & 37.96 & $2,534,500$ & 96209620 & $929,645,000,000$ & $869,520,000,000$ & $60,125,000,000$ & 0.026343519 \\
\hline & 2017 & 42.5 & $1,983,500$ & 84298750 & $998,828,000,000$ & $933,028,000,000$ & $65,800,000,000$ & 0.023529412 \\
\hline
\end{tabular}




\begin{tabular}{|c|c|c|c|c|c|c|c|c|}
\hline BAFL & 2018 & 40.59 & $11,564,000$ & 469382760 & $1,006,218,000,000$ & $930,571,000,000$ & $75,647,000,000$ & 0.02463661 \\
\hline \multirow{5}{*}{$\begin{array}{l}\text { BAHL } \\
\text { BAHL } \\
\text { BAHL } \\
\text { BAHL } \\
\text { BAHL }\end{array}$} & 2014 & 48.55 & $1,377,500$ & 66877625 & $579,394,000,000$ & $546,283,000,000$ & $33,111,000,000$ & 0.020597322 \\
\hline & 2015 & 41.6 & 365,500 & 15204800 & $639,973,000,000$ & $601,832,000,000$ & $38,141,000,000$ & 0.024038462 \\
\hline & 2016 & 58.99 & 616,000 & 36337840 & $768,018,000,000$ & $725,504,000,000$ & $42,514,000,000$ & 0.016952026 \\
\hline & 2017 & 58.36 & 38,000 & 2217680 & $944,134,000,000$ & $898,257,000,000$ & $45,877,000,000$ & 0.017135024 \\
\hline & 2018 & 68.79 & $3,211,500$ & 220919085 & $1,048,239,000,000$ & $998,687,000,000$ & $49,552,000,000$ & 0.014536997 \\
\hline \multirow{5}{*}{$\begin{array}{l}\text { SNBL } \\
\text { SNBL } \\
\text { SNBL } \\
\text { SNBL } \\
\text { SNBL }\end{array}$} & 2014 & 12.33 & 714,000 & 8803620 & $216,473,000,000$ & $199,434,000,000$ & $17,039,000,000$ & 0.081103001 \\
\hline & 2015 & 15.13 & 236,500 & 3578245 & $255,655,000,000$ & $237,463,000,000$ & $18,192,000,000$ & 0.066093853 \\
\hline & 2016 & 17.65 & 412,500 & 7280625 & $281,805,000,000$ & $263,516,000,000$ & $18,289,000,000$ & 0.056657224 \\
\hline & 2017 & 13.4 & 8,500 & 113900 & $325,219,000,000$ & $306,714,000,000$ & $18,505,000,000$ & 0.074626866 \\
\hline & 2018 & 12.67 & 127,000 & 1609090 & $382,498,000,000$ & $364,509,000,000$ & $17,989,000,000$ & 0.078926598 \\
\hline \multirow{5}{*}{$\begin{array}{l}\text { SCBPL } \\
\text { SCBPL } \\
\text { SCBPL } \\
\text { SCBPL } \\
\text { SCBPL }\end{array}$} & 2014 & 23.6 & 2,000 & 47200 & $409,568,000,000$ & $348,852,000,000$ & $60,716,000,000$ & 0.042372881 \\
\hline & 2015 & 21.9 & 3,500 & 76650 & $447,348,000,000$ & $385,397,000,000$ & $61,951,000,000$ & 0.0456621 \\
\hline & 2016 & 25.25 & 36,000 & 909000 & $474,752,000,000$ & $412,049,000,000$ & $62,703,000,000$ & 0.03960396 \\
\hline & 2017 & 23.85 & 500 & 11925 & $519,832,000,000$ & $456,895,000,000$ & $62,937,000,000$ & 0.041928721 \\
\hline & 2018 & 24.12 & 2,500 & 60300 & $576,081,000,000$ & $508,842,000,000$ & $67,239,000,000$ & 0.04145937 \\
\hline
\end{tabular}

